Indonesian Journal of Physics and Nuclear Applications

Volume 3, Number 1, February 2018, p. 29-35

e-ISSN 2550-0570, (C) FSM UKSW Publication

\title{
The Optimization of Collimator Material and In Vivo Testing Dosimetry of Boron Neutron Capture Therapy (BNCT) on Radial Piercing Beam Port Kartini Nuclear Reactor by Monte Carlo N-Particle Extended (MCNPX) Simulation Method
}

\author{
Ikna Urwatul Wusko ${ }^{a}$, Kusminarto ${ }^{a}$, Yohannes Sardjono ${ }^{b^{*}}$ \\ ${ }^{a}$ Physics Department, Faculty of Mathematics and Science-UGM, Sekip Utara \\ Bulaksumur, Yogyakarta 55281, Indonesia \\ ${ }^{\mathrm{b}}$ PSTA-BATAN, Jln. Babarsari Kotak Pos 6010 ykbb, Yogyakarta 55281, \\ Indonesia. \\ *E-mail:sardjono.batan@gmail.com
}

\begin{abstract}
Boron Neutron Capture Therapy (BNCT) on radial piercing beam port Kartini nuclear reactor by MCNPX simulation method has been done in the National Nuclear Energy Agency Yogyakarta. BNCT is a type of therapy alternative that uses nuclear reaction ${ }^{10} \mathrm{~B}(\mathrm{n}, \alpha){ }^{7} \mathrm{Li}$ to produce $2.79 \mathrm{MeV}$ total kinetic energy. To be eligible IAEA conducted a study of design improvements and variations on some parameters to optimum condition which are Ni-nat thickness of $1.75 \mathrm{~cm}$ as collimator wall, $\mathrm{Al}_{2} \mathrm{~S}_{3}$ as thick as $29 \mathrm{~cm}$ as moderator, $\mathrm{Al}_{2} \mathrm{O}_{3} 0.5 \mathrm{~cm}$ thick as filter, $\mathrm{Pb}$ and $\mathrm{Bi}$ thickness of $4 \mathrm{~cm}$ as the end of the gamma shield collimators and Bi thickness of $1.5 \mathrm{~cm}$ as the base gamma shield collimators. The total dose was accepted in the tumor tissue $900 \times 10^{-4} \mathrm{~Gy} / \mathrm{s}$. Radiation dose on the tumor tissue is $50 \pm 3$ Gy with time irradiation of 9 minutes and 10 seconds. That dose was given into skin tissue and healthy liver tissue consecutively $(6.00 \pm 0.05) \times 10^{-2}$ Gy and $(10.00 \pm 0.05) \times 10^{-2}$ Gy. It shows the dose received by healthy tissue is still within safe limits.
\end{abstract}

Keywords Boron Neutron Capture Therapy, Kartini Reactor, in vivo testing, Dosimetry

\section{INTRODUCTION}

Various diseases threaten human health worldwide. According to data from the WHO (World Health Organization) in 2014, the total number of human deaths worldwide was 56 million during 2012, of which 36 million were deaths from non-communicable diseases, or non-communicable diseases (NCDs). There are four predominant types of NCDs, namely cardiovascular diseases, chronic respiratory diseases, diabetes and cancer. The number of deaths caused by cancer cases in the world is 8.2 million people. This is $21.7 \%$ of the total cases of
NCDs mortality data making cancer the second deadliest after heart disease (Anonymous A, 2014).

Cancer is a group of diseases characterized by the growth of cells in the body that are abnormal and uncontrollable spread. Uncontrolled spread of these can lead to death so a therapy is needed to inhibit and eliminate cancer cells (Siegel et al, 2014). Some cancer treatment therapies include surgery, chemotherapy and radiotherapy. All three have weaknesses for conditions such as tumors at an early stage, using drugs which have side effects and also using high-dose radiation. To overcome 
some of these weaknesses Boron Neutron Capture Therapy (BNCT) which is selective against cancer cells (B Anonymous, 2014) has been developed. Kartini reactor neutron source research facility has been used for BNCT. Beam translucent port is used for in vivo tests because the beam port closest to the reactor core giving it a high neutron flux at the base (Widarto, 2002).

\section{MATERIALS AND METHODS}

\subsection{Collimator System Optimization}

Collimator system optimization in this study consists of three parts, namely a moderator, filter and shield gamma. Moderator serves to decrease the energy of fast neutrons for the epithermal neutron energy, so that the parameters used are $\dot{\mathrm{D}}_{\mathrm{f}} / \Phi_{\text {epi }}$ namely fast neutron dose rate per epithermal neutron flux (Soppera et al, 2012). A good criterion moderator material is a material that has a value $\dot{\mathrm{D}}_{\mathrm{f}} / \Phi_{\text {epi }}<2 \times 10^{-13}$ Gy $\mathrm{cm}^{2} / \mathrm{n}$ but the neutron flux values > $1,0 \times 10^{9} \mathrm{n} / \mathrm{cm} 2 \mathrm{~s}$. The filter serves to reduce the thermal neutron flux and fast neutron flux, so that only the epithermal neutron flux is passed. A good criteria filter material is a material that has a high absorption cross section which serves to shield gamma in order to minimize and absorb the gamma rays coming out of the aperture. The criteria for a good gamma shield material are having a density, atomic number and high attenuation coefficient great. Materials that effectively absorb gamma are $\mathrm{Pb}$-nat and ${ }^{209} \mathrm{Bi}$.

\subsection{Object Design in Vivo Testing BNCT}

Simulation geometry test sample used laboratory rats objects already injected with cancer cells. Mouse model which is the reference for the design of in vivo test with specified MCNP Konijnenberg et al (2004) is shown in Figure 2.1. Modeling is done with rats awake approach ellipsoid. Tumor samples used are part of the liver of mice that modeled the ellipsoid shape as well. The geometry modeling agency elipsoida mice with a mouse model is the most simple compared to the BNCT plan models or models Xplan as on research conducted by Liu et al (2014).

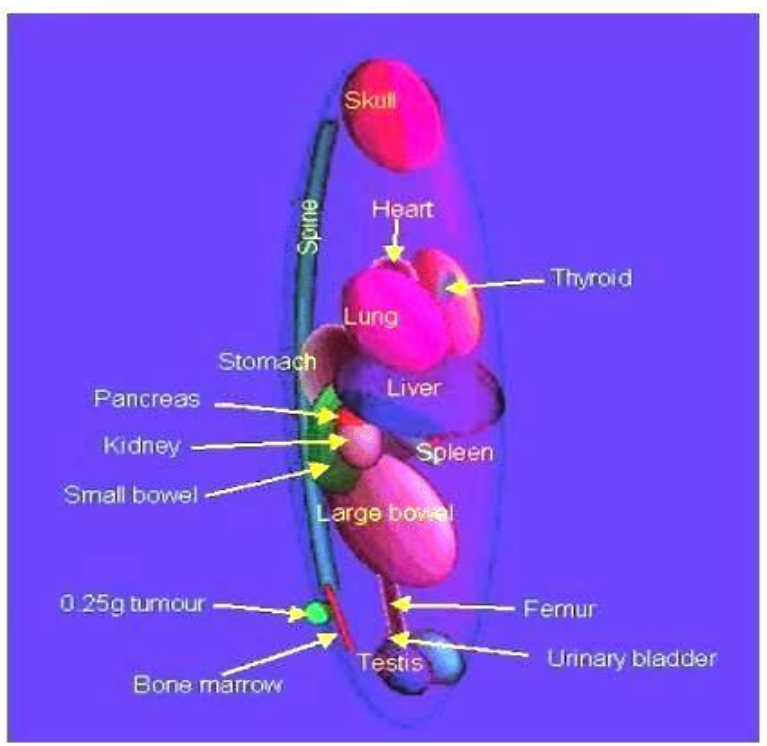

Figure 2.1 Visualization of the model mice

(Konjinenberg et al, 2004)

The output generated from MCNP calculations include gamma dose rate, neutron dose rate, neutron flow and neutron flux values that have been written on the tally code MCNPX. The values resulting from the calculation MCNPX will be used in the calculation of the dose. Boron dose is the dose calculation; dose gamma interacts with matter, dose and dose proton neutron scattering.

\section{RESULTS AND DISCUSSION}

\subsection{The Optimization of Collimator in Radial Piercing Beam Port}

The parts that are used in the optimization of collimator include collimator wall (reflector), moderator, filter and shield gamma. In this study 
Ikna Urwatul Wusko, Kusminarto, Yohannes Sardjono The Optimation of Collimator Material and In Vivo Testing Dosimetry of Boron Neutron Capture Therapy (BNCT) on Radial Piercing Beam Port Kartini Nuclear Reactor by Monte Carlo N-Particle Extended (MCNPX) Simulation Method collimator wall using Ni-nat $156 \mathrm{~cm}$ long and a. Moderation having a thickness of $1.75 \mathrm{~cm}$ Data is derived

Parameters taken into consideration to from previous studies that produced quite high epithermal neutron flux values (Wahyuningsih, 2014) and a diameter of $3 \mathrm{~cm}$ aperture. choose a good moderator were epithermal high flux value, the value of fast neutron component $\dot{\mathrm{D}}_{\mathrm{f}} / \Phi_{\text {epi }}$ epiwere small $\left(<2 \times 10^{-13}\right)$ and epithermal neutron flux ratio with fast neutron flux $\left(\Phi_{\text {epi }} / \Phi_{\text {fast }}\right)$.

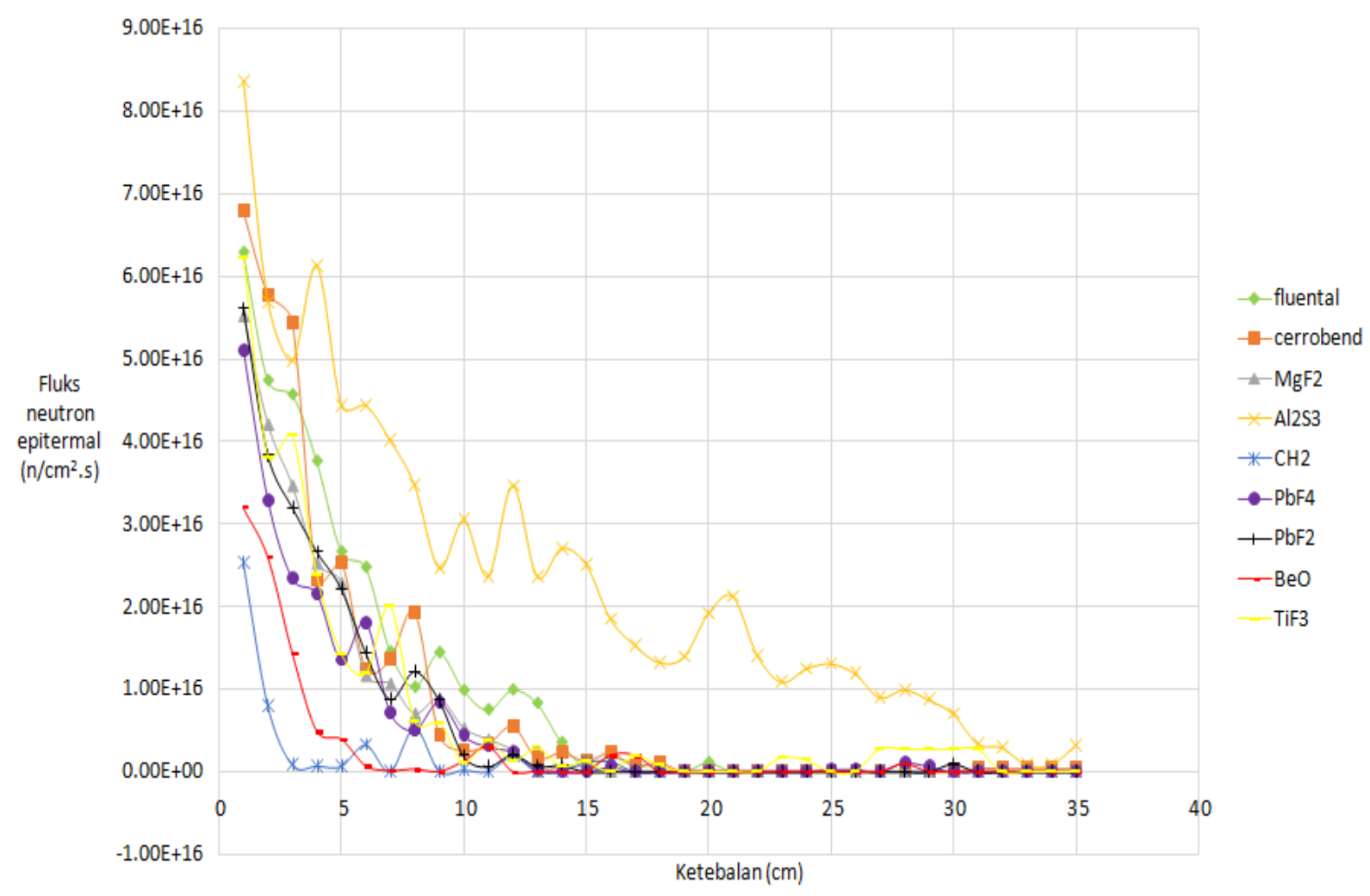

Figure 3.1 Epithermal neutron flux values versus material thickness moderator

Figure 3.1 shows the epithermal neutron flux values for some of the material versus the thickness of the material. As seen in the graph, the material with high value of the thickness, A12S3 has increased thickness epithermal flux values compared to other moderator materials.

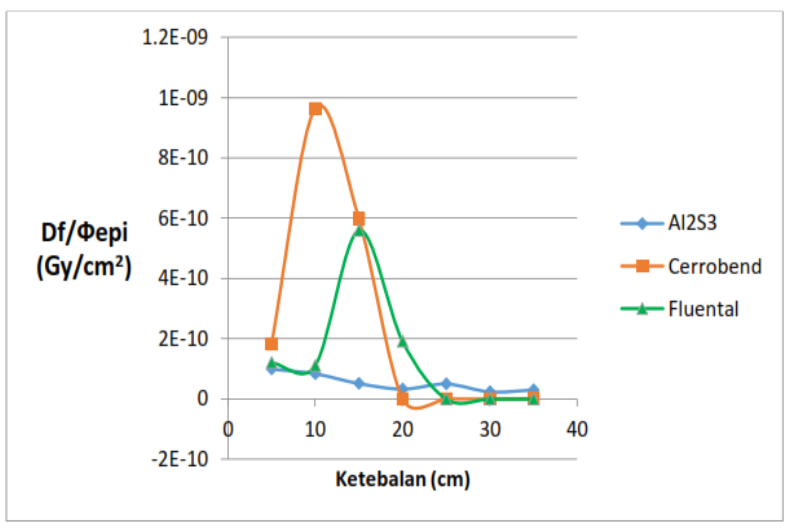

Figure 3.2 Value $\mathrm{D}_{\mathrm{f}} / \Phi_{\text {epi }}$ vs thickness of the material best moderator 
Figure 3.2 shows the value $\mathrm{D}_{\mathrm{f}} / \Phi_{\text {epi }}$ to three different materials versus thickness, the three materials being $\mathrm{Al}_{2} \mathrm{~S}_{3}$, Fluental and Cerrobend. The third election is because the material has a third epithermal neutron flux values higher than in other materials as shown in Figure 3.1. The elements that make up $\mathrm{Al}_{2} \mathrm{~S}_{3}$ have a small mass number. Fluental material is a material consisting of ( $\mathrm{Al} 30 \%+$ $69 \%+\mathrm{LiF} \mathrm{AlF}_{3} 1 \%$ ), and Cerrobend consists of ( $\mathrm{Bi} 50 \%, 31.8 \% \mathrm{~Pb}$ and $\mathrm{Sn} 18.2 \%$ ). Criteria for selection of the best material are when the value $D_{f} / \Phi_{\text {epi }}$ decreases with the value of $\mathrm{D}_{\mathrm{f}} / \Phi_{\text {epi. }}$. From these criteria only Al2S3 still has a high value $D_{\mathrm{f}} / \Phi_{\text {epi }}$ for large thicknesses of data while the other material values $\mathrm{D}_{\mathrm{f}} / \Phi_{\text {epi }}$ are already zero. $\mathrm{Al}_{2} \mathrm{~S}_{3}$ is better as a moderator than the other two materials.

\section{b. Filtering}

Filtering is done to reduce the thermal neutron flux and fast neutron flux, so that only the epithermal neutron flux is passed. Material chosen as the filter was a material that has the look of the reaction $(n, 2 n)$ high. The type of filter used is a band pass filter, intended to effectively skip the epithermal neutron, including $\mathrm{Ni}, \mathrm{Fe}$ and $\mathrm{Al}_{2} \mathrm{O}_{3}$. Using $\mathrm{Al}_{2} \mathrm{O}_{3}$ is intended to determine the effectiveness fast neutron flux filter.

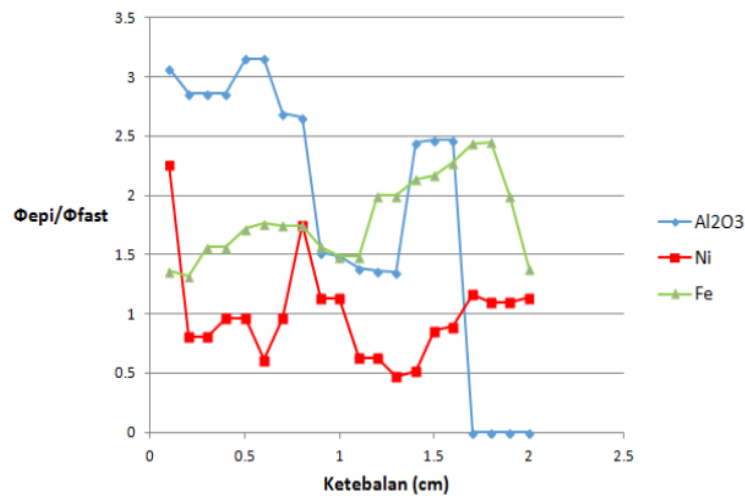

Figure 3.3 Value Фepi/Фfast vs the thickness of the filter material
Figure 3.3 shows materials effective in producing a ratio $\Phi_{\text {epi }} / \Phi_{\text {fast }}$ high are the materials $\mathrm{Al}_{2} \mathrm{O}_{3}$ and ${ }^{56} \mathrm{Fe}$. Low thickness $\mathrm{Al}_{2} \mathrm{O}_{3}$ having highest value of $\Phi_{\text {epi }} / \Phi_{\text {fast }}$, while ${ }^{56} \mathrm{Fe}$ is much lower. But for a much larger thickness value $\Phi_{\text {epi }} / \Phi_{\text {fast }}{ }^{56} \mathrm{Fe}$ material is much higher compared with $\mathrm{Al}_{2} \mathrm{O}_{3}$. This is because the material ${ }^{56} \mathrm{Fe}$ has the ability to filter out the most excellent fast neutrons, but because it is easily corrosive it cannot be used for a relatively long time. Therefore, the use of $\mathrm{Al}_{2} \mathrm{O}_{3}$ with a small thickness is more effective than the use of ${ }^{56} \mathrm{Fe}$ for high thickness. In part the filter material that is most effective is $\mathrm{Al}_{2} \mathrm{O}_{3}$ with a thickness of 0.5 $\mathrm{cm}$.

\section{c. Gamma shielding}

Gamma shield serves to absorb the gamma rays so that magma that comes out of the aperture can be minimized. Two effective materials that absorb gamma-nat is $\mathrm{Pb}$ and ${ }^{209} \mathrm{Bi}$. The following are shown in Table 3.1.

Table 3.1 Value $\Phi_{\text {epi }}$ and $\mathrm{D}_{\gamma} / \Phi_{\text {epi }}$ vs gamma shield material thickness of the end of the collimator

\begin{tabular}{ccc}
\hline $\begin{array}{c}\text { Thickness Pb and } \\
\mathrm{Bi}(\mathrm{cm})\end{array}$ & $\begin{array}{c}\Phi_{\text {epi }} \times \\
10^{9}\left(\mathrm{n} / \mathrm{cm}^{2} \mathrm{~s}\right)\end{array}$ & $\begin{array}{c}\dot{\mathrm{D}}_{\gamma} / \Phi_{\text {epi }} \times \\
10^{-13}(\mathrm{~Gy} \\
\left.\mathrm{cm}^{2} / \mathrm{n}\right)\end{array}$ \\
\hline 1 & 4.4 & 286 \\
\hline 2 & 7.5 & 99 \\
\hline 3 & 6.9 & 82 \\
\hline 4 & 5.4 & 50 \\
\hline 5 & 2.2 & 60 \\
\hline 6 & 2.1 & 81 \\
\hline 7 & 2.1 & 48 \\
\hline 8 & 2.1 & 44 \\
\hline 9 & 2.1 & 21 \\
\hline 10 & 0 & 0 \\
\hline
\end{tabular}


Ikna Urwatul Wusko, Kusminarto, Yohannes Sardjono

The Optimation of Collimator Material and In Vivo Testing Dosimetry of Boron Neutron Capture Therapy (BNCT) on Radial Piercing Beam Port Kartini Nuclear Reactor by Monte Carlo N-Particle Extended (MCNPX) Simulation Method

Election of the end of the gamma shield collimators with $\mathrm{Pb}$ and $\mathrm{Bi}$ constituent material thickness of $4 \mathrm{~cm}$ are due to consideration of the high value $\Phi_{\text {epi }}$ and the value of $\mathrm{D}_{\gamma} / \Phi_{\text {epi }}$ lowest. This value is still higher than the standard IAEA value doses of gamma which must be lower than $2 \times 10^{-13}$ making it necessary to continue efforts to lower it by adding a shield gamma part at the base of the collimator using a type of the same material and varying the thickness of the material.

Table 3.2 shows the value $\mathrm{D}_{\gamma} / \Phi_{\text {epi }}$ much smaller compared to the addition of gamma shield at the end of the collimator only. The result of adding gamma shield at the end of the collimator is a value of $\mathrm{D}_{\gamma} / \Phi_{\text {epi }}$ approximately $50 \times 10^{-13} \mathrm{~Gy} \mathrm{~cm}^{2} / \mathrm{n}$, but after adding a gamma shield at the base of the collimator the value $\mathrm{D}_{\gamma} / \Phi_{\text {epi }}$ decreased to $3.1 \times 10^{-13} \mathrm{~Gy} \mathrm{~cm}^{2} / \mathrm{n}$.

Table 3.2 Value $\dot{\mathrm{D}}_{\gamma} / \Phi_{\text {epi }}$ vs Bi gamma shield material thickness at the base of the collimator

\begin{tabular}{cc}
\hline Thickness $(\mathrm{cm})$ & $\begin{array}{c}\dot{\mathrm{D}}_{\gamma} / \Phi_{\mathrm{epi}} \times 10^{-13}(\mathrm{~Gy} \\
\left.\mathrm{cm}^{2} / \mathrm{n}\right)\end{array}$ \\
\hline 1 & 17.5 \\
\hline 1.1 & 180 \\
\hline 1.2 & 110 \\
\hline 1.3 & 4.4 \\
\hline 1.4 & 3.8 \\
\hline 1.5 & 3.1 \\
\hline 1.6 & 17.8 \\
\hline 1.7 & 20 \\
\hline 1.8 & 6.7 \\
\hline 1.9 & 6.7 \\
\hline 2.0 & 6.4 \\
\hline
\end{tabular}

d. The optimization result

Table 3.3 Results collimator system optimization

\begin{tabular}{|c|c|c|c|c|c|}
\hline Criteria & $\begin{array}{c}\Phi_{\text {epi }} \\
\left(\mathrm{n} / \mathrm{cm}^{2} \mathrm{~s}\right)\end{array}$ & $J / \Phi_{\text {tot }}$ & $\Phi_{\text {term }} / \Phi_{\text {epi }}$ & $\begin{array}{c}\dot{D}_{\mathrm{f}} / \Phi_{\text {epi }} \\
\left(\mathrm{Gy} \mathrm{cm}^{2} / \mathrm{n}\right)\end{array}$ & $\begin{array}{c}\dot{D}_{\mathrm{y}} / \Phi_{\text {epi }} \\
\left(\mathrm{G} \gamma \mathrm{cm}^{2} / \mathrm{n}\right)\end{array}$ \\
\hline IAEA & $>1.0 \times 10^{9}$ & $>0.7$ & $<0.5$ & $<2 \times 10^{-13}$ & $<2 \times 10^{-13}$ \\
\hline Design & $2.92 \times 10^{9}$ & 1.16 & 0.2 & $1.41 \times 10^{-13}$ & $3.15 \times 10^{-13}$ \\
\hline
\end{tabular}

Table 3.3 shows the optimum results from this study with a design specification for reflector collimator system using Ni-nat $156 \mathrm{~cm}$ and a thickness of $1.75 \mathrm{~cm}$, a moderator using the material at a thickness of $29 \mathrm{~cm} \mathrm{Al}_{2} \mathrm{~S}_{3}$, filter using $\mathrm{Al}_{2} \mathrm{O}_{3}$ material with a thickness of $0.5 \mathrm{~cm}$ and a gamma shield at the tip of the collimator using $\mathrm{Pb}$ and $\mathrm{Bi}$ material with a thickness of 4 $\mathrm{cm}$ and gamma shield collimators at the base using a $1.5 \mathrm{~cm}$ thick $\mathrm{Bi}$ material as shown in Figure 3.4.

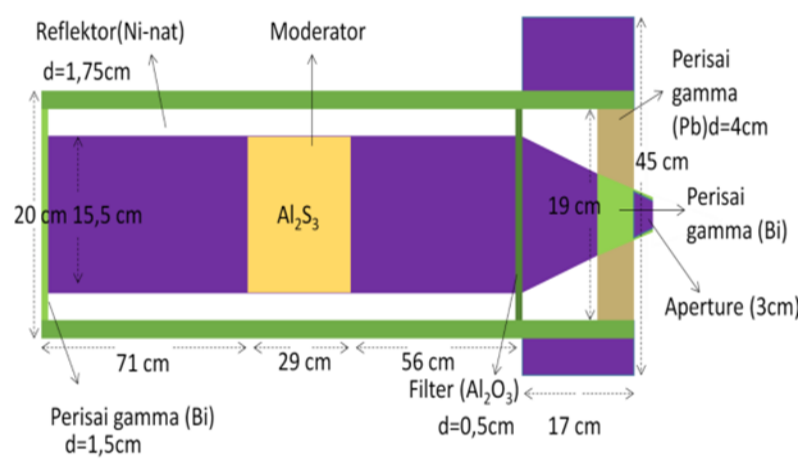

Figure 3.4 the system design collimators

\subsection{The Optimization of Collimator in Radial Piercing Beam Port}

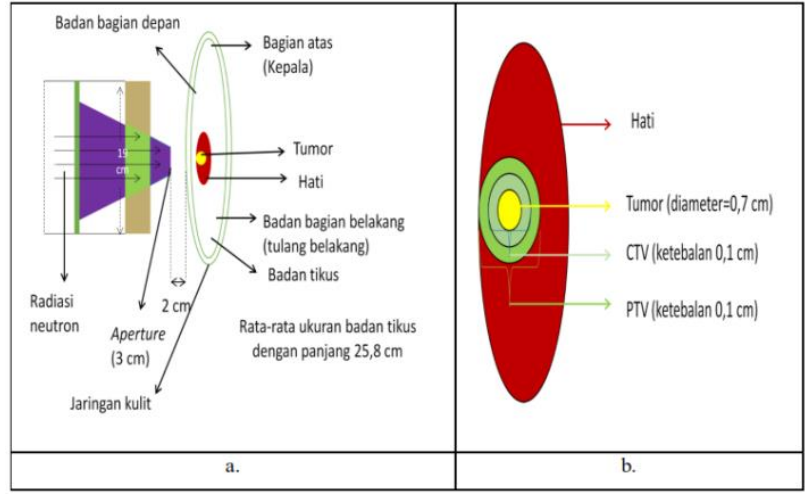

Figure 3.5 a. Design test radiation in vivo liver tumors in mice, $b$. Definition area of the tumor in the liver of mice 
Irradiation techniques on using the technique in one direction, namely towards the front are shown in Figure 3.5. This technique aims to directly irradiate the part closest to the tumor. It will also reduce the radiation in other organs.

Dosimetry BNCT in vivo test on tumor tissue with a maximum dose of irradiation 50 Gy generate a simulated liver tumor tissue in the liver of mice with the irradiation times was $\sim 9$ min. A longer irradiation (radiation) in the tumor tissue is done so that the tumor tissue can be reduced but healthy tissue around it is still in safe dose of radiation.

Table 3.4 Time of irradiation on tumor tissue with the maximum dose

\begin{tabular}{ccccc}
\hline Tissue & Total dose $(\mathrm{Gy} / \mathrm{s})$ & $\begin{array}{c}\text { Maximum dose } \\
\text { standard }(\mathrm{Gy})\end{array}$ & $\begin{array}{c}\text { Irradiation time } \\
\text { tolerance }(\text { second) }\end{array}$ & Irradiation time \\
\hline Tumor & $900 \times 10^{-4}$ & 50 & 555 & $\begin{array}{c}9 \text { minutes } 10 \\
\text { seconds }\end{array}$ \\
\hline
\end{tabular}

Table 3.4 shows the time of irradiation on tumor tissue with the maximum dose. The irradiation time threshold is obtained by using a maximum dose of $50 \mathrm{~Gy}$ to the tumor. The threshold values at the maximum dose of 3 Gy due to skin, when on top of that value, would result in signs of damage to the skin tissue. Exposure to radiation on the skin is more sensitive because the distance is closer to the source of radiation. Radiation maximum threshold dose in the tumor tissue is allowed at $50 \mathrm{~Gy}$. The dose values are the dose to destroy tumor cells.

Table 3.5 Dose in other tissues when irradiated tumor tissue

\begin{tabular}{ccc}
\hline Tissue & $\begin{array}{c}\text { Maximum } \\
\text { dose } \\
\text { standart } \\
\text { (Gy) }\end{array}$ & $\begin{array}{c}\text { Radiation doses to } \\
\text { other tissues to } \\
\text { reduced tumor } \\
\text { tissue }(\mathrm{Gy}) \times 10^{-2}\end{array}$ \\
\hline Skin & 3 & $6.00 \pm 0.05$ \\
\hline $\begin{array}{c}\text { Healty } \\
\text { liver }\end{array}$ & 35 & $10.00 \pm 0.05$ \\
\hline
\end{tabular}

Table 3.5 shows the value of the dose in the skin tissue and the healthy liver tissue when BNCT therapy is done on tumor tissue for in vivo testing. This value is the maximum limit value with long time exposure dose irradiation on the network for 9 minutes 10 seconds to hopefully be able to kill tumor cells that exist in the liver of mice. Value dose to surrounding skin tissue $(6.00 \pm 0.05) \times 10^{-2} \mathrm{~Gy}$ and dose values for healthy liver tissue $(10.00 \pm 0.05) \times 10^{-2}$. Both of these values are far from the limit value of the maximum dose of radiation to the heart tissue and healthy skin of $3 \mathrm{~Gy}$ and $35 \mathrm{~Gy}$ (ICRU, 1989). This is still within the safe limits of radiation to tissue located around the tumor tissue. As a comparison, to reduce tumors in mice after 8 days of mice injected with tumor, it takes 1 hour 17 minutes after irradiation experiments with $\mathrm{BSH}$ as much as $35 \mathrm{mg}$ boron/g (Fujii et al, 2011).

\section{CONCLUSION AND REMARKS}

Based on the results of this study it is concluded:

1. BNCT collimator material optimization for Kartini reactor have been successfully carried out and meet almost all the requirements of the 
Ikna Urwatul Wusko, Kusminarto, Yohannes Sardjono The Optimation of Collimator Material and In Vivo Testing Dosimetry of Boron Neutron Capture Therapy (BNCT) on Radial Piercing Beam Port Kartini Nuclear Reactor by Monte Carlo N-Particle Extended (MCNPX) Simulation Method IAEA.

Liu, Y.H., Lee, P.Y., Lin, Y.C., Chou, F.I., Chen, W.L., Huang, Y.S. and Jiang, S.H., 2014, Dose estimation of animal experiments at the THOR BNCT beam by NCTPlan and Xplan, Applied Radiation and Isotopes, vol.88, page. 125-128.

Siegel, R., Ma, J., Zou, Z. and Jemal, A., 2014, Cancer Statistics 2014, CA Cancer J Clinical, vol. 64, page. 9-29.

Soppera, N., Dupont, E. and Bossant, M., 2012, Javabased Nuclear Information Software: Book of Neutron-induced Cross-section, A technical document, Nuclear Energy Agency, Issy-lesMoulineaux.

tumor tissue of $50 \pm 3$ Gy is irradiation time of 9 minutes 10 seconds. The radiation dose received in the skin tissue and the healthy liver tissues respectively are $(6.00 \pm 0.05) \times$ $10^{-2} \mathrm{~Gy}$ and $(10.00 \pm 0.05) \times 10^{-2} \mathrm{~Gy}$. The dose values are still quite low compared to the value of the dose received by the tumor tissue. It shows the radiation exposure of healthy tissue around the tumor tissue is still within safe limits.

\section{ACNOWLEDGEMENT}

This research was supported by grants from consortium of BNCT BATAN Yogyakarta.

\section{REFERENCES}

Anonymous A, 2014, Global Status Report on Noncommunicable Diseases, World Health Organization (WHO), Prancis.

Anonymous B., 2014, Radiation Therapy and You, National Cancer Institute, USA.

Fujii, H., Matsuyama, A., Komoda, H., Sasai, M., Asano, T., Doki, Y., Kirihata, M., Ono, K., Tabata, Y., Kaneda, Y., Sawa, Y. and lee, C.M., 2011, Cationized gelatin-HVJ envelope with sodium borocaptate improved the BNCT efficacy for liver tumor in vivo, Radiation Oncology, 6:8.

International Commision on Radiations Unit and Measurements Report 44, 1989, Dokumen Teknis. USA.

Konijnenberg, M.W., Bijster, M., Krenning, E.P. and de Jong, M., 2004, A Stylized Computational Model of the Rat for Organ Dosimetry in Support of Preclinical Evaluations of Peptide Receptor radionuclide Therapy with 90Y, 111In, or $177 \mathrm{Lu}$, The Journal of Nuclear Medicine, vol. 45 , page. $1260-1269$. 